\title{
TNF- $\alpha$ Opens a Paracellular Route for HIV-1 Invasion across the Blood-Brain Barrier
}

\author{
Milan Fiala, ${ }^{1}$ David J. Looney, ${ }^{9}$ Monique Stins, ${ }^{7}$ Dennis D. Way, ${ }^{8}$ \\ Ling Zhang, ${ }^{2}$ Xiaohu Gan, ${ }^{2,3}$ Francesco Chiappelli, ${ }^{4,5}$ \\ Erik S. Schweitzer, ${ }^{4}$ Paul Shapshak, ${ }^{6}$ Martin Weinand, ${ }^{8}$ \\ Michael C. Graves, ${ }^{2}$ Marlys Witte, ${ }^{8}$ and Kwang Sik Kim ${ }^{7}$ \\ Departments of ${ }^{1}$ Medicine, ${ }^{2}$ Neurology, ${ }^{3}$ Microbiology and \\ Immunology, and ${ }^{4}$ Neurobiology, UCLA School of Medicine, \\ Los Angeles, California, U.S.A. \\ ${ }^{5}$ Division of Diagnostic Sciences, UCLA School of Dentistry, \\ Los Angeles, California, U.S.A. \\ ${ }^{6}$ Departments of Psychiatry, Neurology, and Pathology, \\ University of Miami, Miami, Florida, U.S.A. \\ ${ }^{7}$ Division of Infectious Diseases, Children's Hospital, Los Angeles, \\ California, U.S.A. \\ ${ }^{8}$ Department of Surgery, University of Arizona School of Medicine, \\ Tucson, Arizona, U.S.A. \\ ${ }^{9}$ Department of Medicine, University of California-San Diego, \\ San Diego, California, U.S.A.
}

\begin{abstract}
Background: HIV-1 invades the central nervous system early after infection when macrophage infiltration of the brain is low but myelin pallor is suggestive of bloodbrain-barrier damage. High-level plasma viremia is a likely source of brain infection. To understand the invasion route, we investigated virus penetration across in vitro models with contrasting paracellular permeability subjected to TNF- $\alpha$.

Materials and Methods: Blood-brain-barrier models constructed with human brain microvascular endothelial cells, fetal astrocytes, and collagen I or fibronectin matrix responded in a dose-related fashion to cytokines and ligands modulating paracellular permeability and cell migration. Virus penetration was measured by infectious and quantitative HIV-1 RNA assays. Barrier permeability was determined using inulin or dextran.
\end{abstract}

Results: Cell-free HIV-1 was retained by the blood-brain barrier with close to $100 \%$ efficiency. TNF- $\alpha$ increased virus penetration by a paracellular route in a dose-dependent manner proportionately to basal permeability. Brain endothelial cells were the main barrier to HIV-1. HIV-1 with monocytes attracted monocyte migration into the brain chamber.

Conclusions: Early after the infection, the blood-brain barrier protects the brain from HIV-1. Immune mediators, such as TNF- $\alpha$, open a paracellular route for the virus into the brain. The virus and viral proteins stimulate brain microglia and macrophages to attract monocytes into the brain. Infiltrating macrophages cause progression of HIV-1 encephalitis.

\section{INTRODUCTION}

Human immunodeficiency virus type 1 (HIV-1) is found in the cerebrospinal fluid (CSF) of

Address correspondence and reprint requests to: Dr. Milan Fiala, Reed Neurology Research Institute, Rm 21-50, UCLA School of Medicine, 710 Westwood Plaza, Los Angeles, CA 90095-1769, U.S.A. Phone: 310-206-6392; fax: 310-8253995; e-mail: fiala@ucla.edu asymptomatic HIV-1-infected individuals early after the initial infection (1). The virus may penetrate into the CSF across either the blood-brain barrier (BBB), the blood-CSF barrier in the choroid plexus (2), the circumventricular organs that lack the $\mathrm{BBB}$, or via peripheral and cranial nerve axons (3). Potential mechanisms of virus invasion of the brain include receptor-mediated transcytosis, a mechanism demonstrated with 
pseudorabies virus (4) and with HIV-l (across epithelial monolayers) (5); a paracellular route between endothelial cells (shown here); endothelial cell infection as suggested with simian immunodeficiency virus (SIV) (6) and lymphotropic HIV-1 $(7,8)$; disruption of the blood-brain barrier by perivascular "activated" macrophages (9); and the "Trojan horse" mechanism, postulated a decade ago (10) and recently shown mechanistically by transmigration of LPS-activated monocytes carrying HIV-1 across a BBB model (11). At an early stage of AIDS, however, infectious virus is generally not found in circulating blood monocytes (12), and in the brain, macrophages, multinucleated giant cells, and viral proteins are low or absent, whereas vasculitis and myelin pallor, reflecting BBB damage, are common (13). Tumor necrosis factor $\alpha$ (TNF- $\alpha$ ) is a potential cause of this damage because of its ability to increase the permeability of brain endothelial cells (14). Furthermore, early after the infection plasma viremia titers may be extremely high-up to $10^{7}$ viral RNA copies per ml of blood $(15,16)$. BBB integrity is therefore of key importance in protection against infection of the brain by HIV-1 viremia.

To investigate the role of BBB in HIV-1 infection of the brain, we developed an in vitro model of the BBB (17) which includes the components of the human BBB: brain endothelial cells, astrocytes, and the basement membrane matrix. The results of this study show that endothelial cells play a key role as a barrier to HIV-1, which can, however, penetrate between endothelial cells by a paracellular route opened by TNF- $\alpha$. These observations suggest that in vivo the intact BBB may initially provide protection against blood-borne HIV-l; however, the BBB becomes compromised by HIV-1-induced inflammatory cytokines, chemokines, and leukotrienes acting in a paracrine and autocrine manner on brain endothelial cells.

\section{MATERIALS AND METHODS}

\section{Cell Culture and Virus}

Adult brain microvascular endothelial cells were derived from nonepileptogenic lateral temporal cortex tissues obtained during surgical removal of epileptogenic foci in the medial temporal lobe $(18,19)$. Pediatric brain endothelial cells were prepared from surgical specimens of the cerebral cortex from children with seizure disorders (20).
The brain tissue was dissociated and cultured by the techniques described previously $(19,20)$, and the outgrowing cells were cultured in DME/F-12 (Sigma, St. Louis, MO) with $10 \%$ fetal bovine serum, 25 mM HEPES ( $\mathrm{pH} 7.2-7.4$ ), bicarbonate $(0.14 \%)$, endothelial cell growth supplement ( 50 $\mu \mathrm{g} / \mathrm{ml}$ ) (H-Neurext, Upstate Biotechnology, Lake Placid, NY), penicillin $(100 \mathrm{u} / \mathrm{ml})$, streptomycin $(100 \mu \mathrm{g} / \mathrm{ml})$, and fungizone $(0.25 \mu \mathrm{g} / \mathrm{ml}$ ) (referred to as DME-S) to which heparin was initially added $(100 \mu \mathrm{g} / \mathrm{ml})$. Each cell line had cobblestone morphology, and each was positive for endothelial cell markers, factor VIII-related antigen, and Ulex europaeus agglutinin, as determined by flow cytometric analysis and immunocytochemistry with rabbit antibody to von Willebrand factor and Ulex europeus agglutinin (DAKO, Carpinteria, CA) (11). The cells were negative by staining with mouse antihuman glial fibrillary acidic protein and mouse anti-CD56 and anti-CD68 antibodies. Glucose transporter isoform type 1 (GLUT-1) and occludin antigens were demonstrated at an early passage by immunocytochemical staining utilizing rabbit antibody to GLUT-1 (21) or occludin (Zymed Labs., South San Francisco, CA), respectively. Light microscopy and transmission electron microscopy revealed uniformly flat and tightly adjoining endothelial cells covering the porous membrane completely and displaying areas of cell membrane fusion between adjoining cells resembling zonula adhaerens (desmosome) junctions (22). Human fetal astrocytes (HFA) were prepared as described by Tornatore et al. (23) and were $100 \%$ positive by immunocytochemistry with rabbit antibody to glial fibrillary acidic protein (DAKO). The A3.01 cell line, a human T cell line derived from the buffy coat of a patient with lymphoblastic leukemia and susceptible to HIV-1, was obtained from the AIDS Research and Reference Reagent Program, Division of AIDS, NIAID, NIH (24) and used for infectious virus assay.

HIV- $1_{J R-F L}(25)$, an HIV-1 strain isolated from the frontal lobe tissue of a patient with AIDS encephalopathy, was grown in normal human umbilical cord mononuclear cells stimulated by interleukin-2 (IL-2; Amgen, Thousand Oaks, CA) (10 U/ml) and phytohemagglutinin-A (Sigma Chemical Co., St. Louis, MO) $(0.5 \mu \mathrm{g} / \mathrm{ml})$ for 10 days, after which the supernatant medium was separated by centrifugation and stored frozen in aliquots. 


\section{Blood-Brain-Barrier Model}

The model was constructed in tissue culture inserts with Cyclopore polyethylene terephthalate membranes $\left(2 \times 10^{6}\right.$ pores $/ \mathrm{cm}^{2}$ [pore diameter of $3 \mu \mathrm{m}$ ) ) coated with collagen type I (rat tail) and human fibronectin $(50 \mu \mathrm{g} / \mathrm{ml})$ (all from Collaborative Biomedical Products, Bedford, MA) with brain endothelial cells on the top (bloodside) and human fetal astrocytes on the bottom (brain-side) according to previously published concepts $(26,27)$. MATRIGEL basement membrane matrix (Becton Dickinson/Collaborative Biomedical Products, Bedford, MA) was tested but not used further. Adult endothelial cells in an in vitro passage 2-6 were used in most experiments. Pediatric endothelial cells were used in the experiment described in Fig. 4. To coat the lower surface with astrocytes, a suspension of $3 \times 10^{4}$ astrocytes in $1 \mathrm{ml}$ of DME-S was placed in a cut-off bulb-end of a sterile disposable pipette (Liquipette, Elkay Productis, Shrewsbury, MA) and the lower end of the insert was inserted aseptically into the bulb, which made a tight seal. The bulb with the insert was then inverted and incubated at $37^{\circ} \mathrm{C}$ for $4 \mathrm{hr}$ to allow the HFA to attach to the membrane. Following this incubation, the bulb was removed and the insert placed right side up in a 24-well tray. A suspension of $0.4 \times 10^{4}$ brain endothelial cells in $0.31 \mathrm{ml}$ DME-S was placed in the upper chamber of the insert and $1 \mathrm{ml}$ of DME-S was placed in the lower chamber.

\section{IL-6 Assay}

IL-6 was assayed by ELISA as described previously (28).

\section{Electrical Resistance}

This was measured using the Millicell-ERS apparatus (Millipore, Bedford, Mass) by means of AC current after placing one $\mathrm{Ag} / \mathrm{AgCl}$ electrode (World Precision Instruments, Sarasota, FL) in the upper chamber (0.1-0.2 ml media) and the other electrode in the lower chamber of the model $(0.5 \mathrm{ml}$ media). Electrodes were sterilized using $95 \%$ alcohol followed by rinsing in distilled water, and were maintained at a constant distance $(0.6 \mathrm{~cm})$ between electrodes. The background resistance of a membrane without cells was monitored in successive experiments. The average background resistance (136-161 ohm) was subtracted from the resistance of an experi- mental model and this value was multiplied by the surface area $\left(0.31 \mathrm{~cm}^{2}\right)$ as follows:

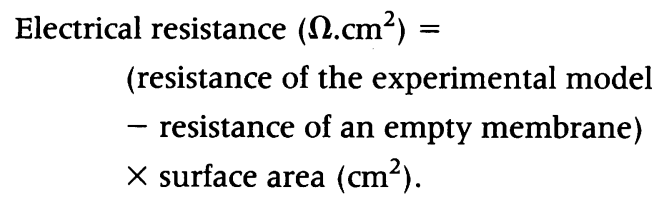

\section{Molecular Permeability}

This was assessed by a diffusion assay using ${ }^{14} \mathrm{C}$ carboxylated inulin (MW 5000) or ${ }^{14} \mathrm{C}$-methylated dextran (MW 2,000,000) in the upper chamber. After incubation for 1,4 , and $24 \mathrm{hr}$ at $37^{\circ} \mathrm{C}, 50-\mu \mathrm{L}$ samples were taken from the bottom chamber.

The coefficient of ${ }^{14} \mathrm{C}$-inulin or ${ }^{14} \mathrm{C}$-dextran permeability (29) was calculated using the formula

$$
\{V /(A * D)\} *\{\Delta R / \Delta T\},
$$

where $V=$ volume of the receptor chamber $\left(1.0 \mathrm{~cm}^{3}\right), A=$ area of the cell monolayer on the membrane $\left(0.36 \mathrm{~cm}^{2}\right), D=$ initial amount of the marker molecule in the donor chamber, $\Delta R / \Delta T=$ amount of the marker molecule in the receiver solution $(\Delta T=1$ or $4 \mathrm{hr})$.

\section{Transmigration of Monocytes}

Human blood monocytes were obtained by a modification of the Recalde procedure (30). For inhibition studies, the lower chamber was treated with IL- $1 \beta(2 \mathrm{ng} / \mathrm{ml})$ and monocyte chemotactic protein 1 (MCP-1) (RED Systems, Minneapolis, $\mathrm{MN})(10 \mathrm{ng} / \mathrm{ml})$, and the upper chamber was treated with each monoclonal antibody at a final concentration of 20 $\mu \mathrm{g} / \mathrm{ml}$ for $1.5 \mathrm{hr}$. The following antibodies were used with specificity (identification): (a) $\beta 1$ (15/7), $\beta 2$ (IB4), $\alpha 4$ (L25) integrins (Athena Neurosciences, South San Francisco, CA); (b) VCAM-1 (11/33 and 11/47) (Athena Neurosciences), VCAM-1 (4B9) (T. Carlos, University of Pittsburgh, PA); and (c) PECAM-1 (W.A. Muller, Rockefeller University, New York, NY). After removing the antibody from the upper chamber, 1 million human monocytes were added into the upper chamber and were incubated for $20 \mathrm{hr}$ when the contents of the lower chamber were aspirated and cell concentration was determined by a Coulter counter. 


\section{HIV Assays}

INFECTIOUS VIRUS. This was measured by adding a $50-\mu \mathrm{L}$ sample from the lower chamber to a $1-\mathrm{ml}$ suspension of $2 \times 10^{5} \mathrm{~A} 3.01$ cells in RPMI medium with $10 \%$ fetal calf serum. After 5 days of incubation, the wells with A3.01 cells were harvested by centrifugation and p24 antigen concentration was measured in the supernatant by the Coulter HIV-1 p24 antigen assay (Coulter, Hialeah, FL). HIV-1 replication in A3.01 cells suspended in the unsupplemented medium or medium with $10 \mathrm{ng} / \mathrm{ml}$ of TNF- $\alpha$ resulted in $\mathrm{p} 24$ antigen titers that were not significantly different.

HIV-1 RNA ASSAY. The Amplicor HIV Monitor Test was performed according to manufacturer's suggested procedure, as discussed by others $(31,32)$. Briefly, $50-\mu \mathrm{L}$ samples were diluted 1:4 with phosphate-buffered saline (PBS) and vortexed for $5 \mathrm{sec}$. Two hundred microliters of each sample was added to Sarstedt $2.0-\mathrm{ml}$ tubes containing $600 \mu \mathrm{L}$ lysis reagent together with the indicated volume of quality standard (QS) for the QS lot, tubes were incubated for $10 \mathrm{~min}$ at $20^{\circ} \mathrm{C}$, and $800 \mu \mathrm{L}$ isopropanol was added. After again vortexing for $5 \mathrm{sec}$, samples were centrifuged for 15 min at $16,000 \mathrm{~g}$, the supernatants discarded, and the pellets washed twice with $70 \%$ ethanol and resuspended in $400 \mu \mathrm{L}$ specimen diluent. Then 50- $\mu \mathrm{L}$ samples were added to MicroAmp tubes containing $50 \mu \mathrm{L}$ master PCR mix. Reverse transcription was performed for $2 \mathrm{~min}$ at $50^{\circ} \mathrm{C}$ and 30 $\min$ at $60^{\circ} \mathrm{C}$. Polymerase chain reaction (PCR) amplification was performed using the following conditions: $95^{\circ} \mathrm{C}$ for $10 \mathrm{sec}, 55^{\circ} \mathrm{C}$ for $10 \mathrm{sec}, 72^{\circ} \mathrm{C}$ for $10 \mathrm{sec}(4 \mathrm{cycles})$, nd then $90^{\circ} \mathrm{C}$ for $10 \mathrm{sec}$, $60^{\circ} \mathrm{C}$ for $10 \mathrm{sec}$, and $72^{\circ} \mathrm{C}$ for $10 \mathrm{sec}(26 \mathrm{cycles})$. Terminal extension was performed for $15 \mathrm{~min}$ at $72^{\circ} \mathrm{C}$. Following amplification, products were denatured by adding $100 \mu \mathrm{L}$ denaturing solution, $25 \mu \mathrm{L}$ of each sample was added to $100 \mu \mathrm{L}$ of hybridization solution in the assay microwell plate. Samples were then serially diluted $(1: 5,25$ $\mu \mathrm{L}$ ) and plates incubated for $1 \mathrm{hr}$ at $37^{\circ} \mathrm{C}$ and washed five times. After addition of avidin-HRP conjugate $(100 \mu \mathrm{L})$ to each well, the plates were incubated for $15 \mathrm{~min}$ at $37^{\circ} \mathrm{C}$ and again washed five times. Substrate solution $(100 \mu \mathrm{L})$ was added to each well, plates developed in darkness for $10 \mathrm{~min}$ at $20^{\circ} \mathrm{C}$, and reaction stopped by the addition of stop solution to each well $(100 \mu \mathrm{L})$. Optical densities were read at $450 \mathrm{~nm}$ and copy number was calculated according to the manufacturer's directions.

\section{Exposure of Brain Endothelial Cells to HIV-1}

Monolayers with 250,000 adult brain microvascular endothelial cells (BMVEC) were exposed to $2 \mathrm{ng}$ of p24 (1.5 $\times 10^{8}$ RNA copies) of HIV- $1_{\mathrm{JR}-\mathrm{FL}}$ washed four times, and incubated at $37^{\circ} \mathrm{C}$. On Days 2, 4, 6, 8, 10, 12, and 29 and 79 days post-infection, one monolayer was pretreated with TNF- $\alpha(100 \mathrm{ng} / \mathrm{ml})$ for $24 \mathrm{hr}$ and another was left untreated. Two 50- $\mu \mathrm{L}$ samples were collected from each culture supernatant and tested by p24 antigen and HIV infectious assays.

\section{Statistical Analysis}

Comparisons of means versus concentration and/or time were carried out using analysis of variance methods (ANOVA) on a log scale (log transform). The Turkey LSD method was used to compute post hoc $t$ statistics and corresponding $p$ values. 95\% confidence intervals for mean differences were computed as mean difference \pm $t_{0,975} \times$ standard error (S.E.) of mean difference where the value of $t$ has $\left(\mathrm{n}_{1}+\mathrm{n}_{2}-2\right)$ degrees of freedom. Means are significantly different if the confidence interval for their difference does not contain zero (33). Each experiment was repeated at least once with essentially the same results.

\section{RESULTS}

\section{Molecular Permeability, Electrical Resistance, and Cell Migration across the Brain Endothelial-Astrocyte Bilayer Are Regulated by the Extracellular Matrix and Modulated by TNF- $\alpha$}

In order to study HIV-1 neuroinvasiveness, we constructed a human BBB model based on previous concepts $(26,27)$ with endothelial cells and extracellular matrix on the upper side and astrocytes on the lower side of a porous membrane (Fig. 1). The extracellular matrix communicates via integrins to endothelial cells providing the signals for the formation of tight intercellular junctions (34). The models constructed on collagen I or IV had a relatively low permeability coefficient for the paracellular marker inulin $(0.0009-0.001 \mathrm{~cm} / \mathrm{min})$ and a relatively high electrical resistance $\left(76-98 \Omega . \mathrm{cm}^{2}\right)$, whereas those on fibronectin matrix had a relatively high 
A

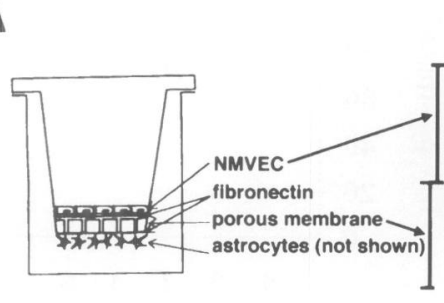

B

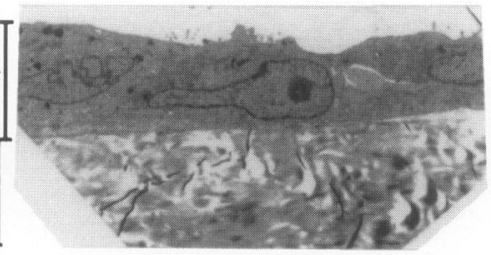

C

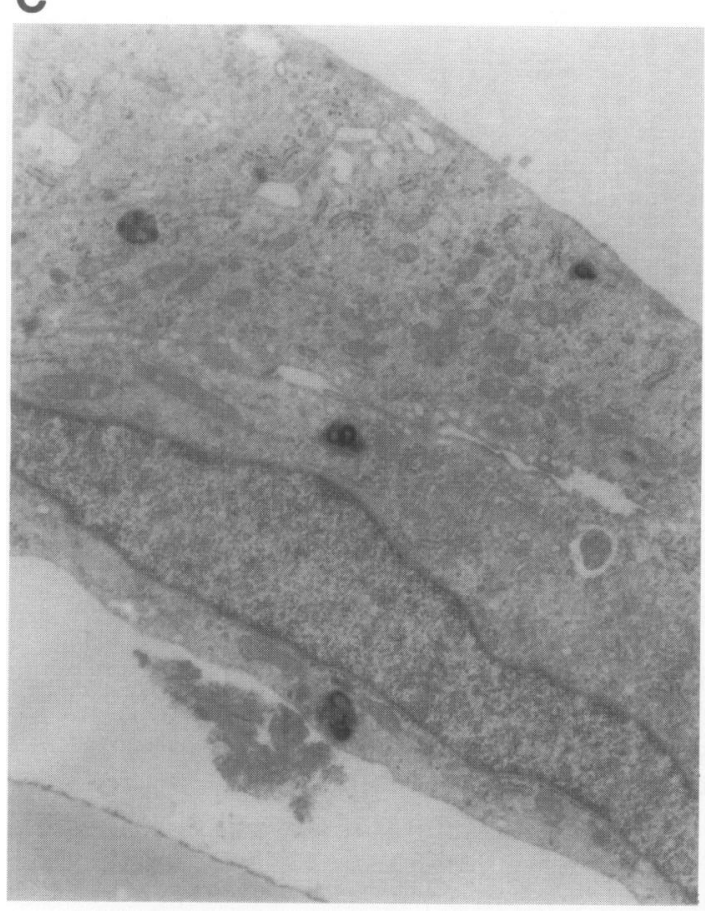

D

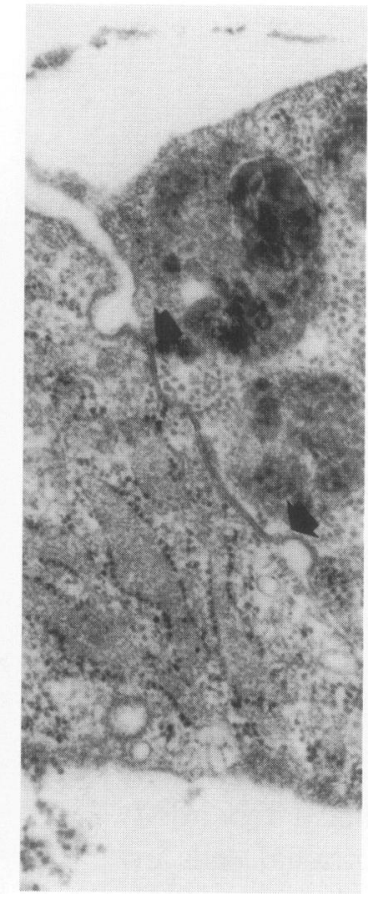

FIG. 1. Blood-brain-barrier model

(A) Design of the bilayer model with brain neural microvascular endothelial cells (BMVEC), fibronectin or collagen Ifibronectin matrix, membrane, and astrocytes. (B, C) Transmission electron microscopy of a vertical cross section across the endothelial layer showing cells in close apposition $(\times 3000$ and $\times 6800$, respectively). (D) Fusion of cell membranes between adjoining cells resembling zonula adhaerens $(\times 22,000)$.

TABLE 1. ${ }^{14} \mathrm{C}$-inulin permeability and monocyte transmigration across a brain microvascular endothelial barrier cultured on various extracellular matrix ${ }^{a}$

\begin{tabular}{lcc}
\hline $\begin{array}{l}\text { Extracellular } \\
\text { Matrix }\end{array}$ & $\begin{array}{c}\text { Coefficient of Permeability } \\
\text { to }{ }^{\mathbf{1 4}} \text { C-inulin }(\mathbf{c m} / \mathbf{m i n})^{\boldsymbol{b}}\end{array}$ & $\begin{array}{c}\text { No. of Transmigrated } \\
\text { Monocytes }^{\boldsymbol{b}}\end{array}$ \\
\hline None & $0.0032 \pm 0.0001$ & $>10,000$ \\
Collagen I-rat tail & $0.0010 \pm 0.0000$ & $634 \pm 64$ \\
Collagen IV-mouse & $0.0009 \pm 0.0001$ & N.D. \\
Collagen I-fibronectin & $0.0009 \pm 0.0001$ & N.D. \\
Human fibronectin & $0.0023 \pm 0.0009$ & $1758 \pm 252$ \\
Mouse laminin & $0.0017 \pm 0.0008$ & N.D. \\
MATRIGEL & $0.0003 \pm 0.0000$ & $0 \pm 0$
\end{tabular}

${ }^{a} 40,000$ brain endothelial cells were seeded into inserts with a terephthalate membrane bottom coated with specified matrix and cultured for 3 days.

${ }^{b}$ Mean \pm S.D.M.; N.D., not determined. 


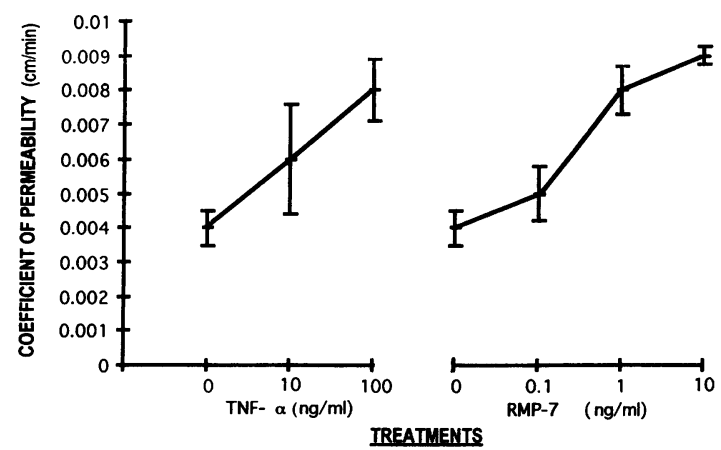

FIG. 2. TNF- $\alpha$ and RMP-7 increase the permeability of the endothelial-astrocyte bilayer

The BBB models were prepared with 40,000 brain endothelial cells and 40,000 astrocytes in DME-S on collagen I-fibronectin-coated inserts and cultured for 3.5 days at $37^{\circ} \mathrm{C}$. The models were then treated for $4 \mathrm{hr}$ with DME-S containing no addition, TNF- $\alpha$ ( 10 or $100 \mathrm{ng} / \mathrm{ml}$ ), or RMP-7 $(0.1,1$ or $10 \mathrm{ng} / \mathrm{ml}$ ) simultaneously with the addition of ${ }^{14} \mathrm{C}$-inulin. The permeability coefficient was determined as described in Materials and Methods.

permeability $(0.0023 \mathrm{~cm} / \mathrm{min})$ and low electrical resistance (19-23 $\Omega . \mathrm{cm}^{2}$ ) (Table 1). MATRIGEL matrix did not respond to physiological ligands and was therefore not used in HIV-1 experiments. The tightness of the model also depended on in vitro passage history (endothelial cells in passage 6 had higher permeability than passage 2 cells), the time in culture (4 days were optimal), and the number of cells planted in each insert. The permeability was related indirectly to the MW of the tracer $(0.001 \mathrm{~cm} / \mathrm{min}$ with inulin [MW 5000] and $0.00025 \mathrm{~cm} / \mathrm{min}$ with dextran [MW 2,000,000]). Madin-Darby canine kidney (MDCK), a tight epithelial cell monolayer, had lower permeability $(0.0004 \pm 0.00007 \mathrm{~cm} / \mathrm{min})$, whereas choroid plexus endothelia had higher permeability $(0.002 \mathrm{~cm} / \mathrm{min})$ compared with brain endothelial cells $(0.0009 \mathrm{~cm} / \mathrm{min})$. The standard model for HIV experiments was therefore constructed using a combination of collagen I and fibronectin matrix with 40,000 brain endothelial cells and 40,000 astrocytes on terephthalate membrane $\left(0.36 \mathrm{~cm}^{2}\right)$.

Since immune-activated monocytes play an important role in virus invasion in vitro (11) and in vivo (35), we investigated regulation of monocyte transmigration in the model. Leukocyte migration is orchestrated by leukocyte-endothelial adhesion molecules, selectins, Ig-like proteins, and integrins (36). Accordingly, in the model, antibodies to $\beta 2$, but not $\beta 1$, and integrin and
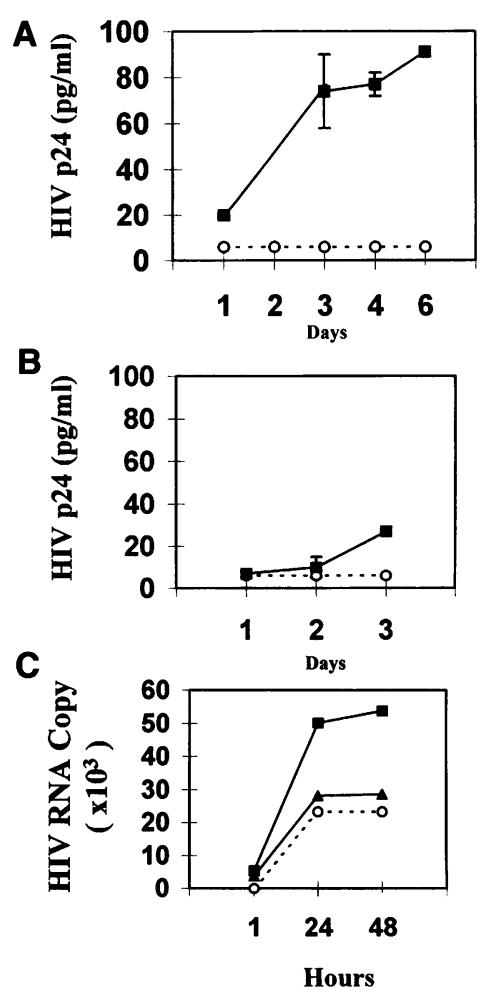

FIG. 3. TNF- $\alpha$ enhancement of HIV-1 penetration is greater in models with high basal permeability compared with models with low basal permeability

Models (4 days in culture) were were treated with DME-S (circles), DME-S with TNF- $\alpha(10 \mathrm{ng} / \mathrm{ml})$ (triangles), or DME-S with TNF- $\alpha(100 \mathrm{ng} / \mathrm{ml})$ (squares) for $2 \mathrm{hr}$ prior to and during the whole experiment. HIV-1 was placed in the upper chamber (2.1 $\mathrm{ng}$ in A and B, and $50 \mathrm{pg}$ in C). Samples (50 $\mu \mathrm{L}$ ) for virus assay were removed from the lower chamber at indicated intervals and were measured by infectious virus assay (A and B), or HIV RNA assay (C). (A) Model constructed on fibronectin matrix (coefficient of permeability $0.0023 \mathrm{~cm} / \mathrm{min}$ ) measured by infectious virus assay. (B) Model constructed on collagen I-fibronectin (coefficient of permeability $0.0009 \mathrm{~cm} / \mathrm{min}$ ) measured by infectious virus assay. (C) Model constructed on collagen I-fibronectin (coefficient of permeability 0.0009 $\mathrm{cm} / \mathrm{min}$ ) measured by virus RNA assay.

antibodies to VCAM-1 were found to inhibit cell transmigration by up to $50 \%$ (data not shown). Monocyte transmigration was regulated by endothelial cells in synergy with the extracellular matrix but not by the endothelial monolayer alone (Table 1).

TNF- $\alpha$, a proinflammatory cytokine, increases the paracellular permeability of bovine brain endothelial cells $(14,37)$. Bradykinin, a B2 receptor agonist, is a physiologic regulator of the 


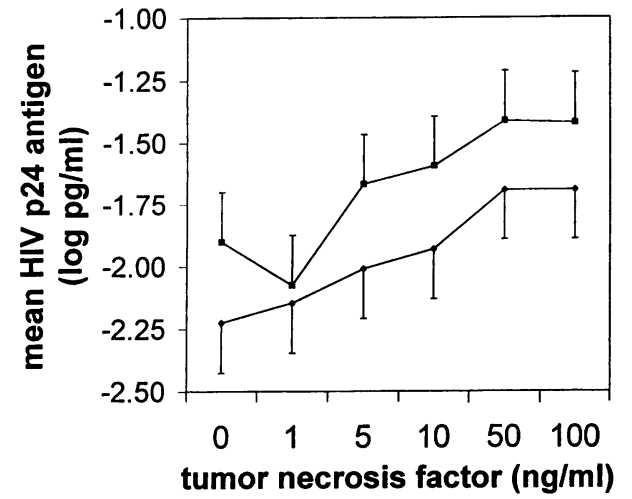

FIG. 4. TNF- $\alpha$ enhances HIV-1 penetration across the BBB model in a dose-responsive fashion

BBB models (constructed with pediatric endothelial cells on collagen I-fibronectin matrix) were treated with DME-S without or with TNF- $\alpha$ (0 to $100 \mathrm{ng}$ / $\mathrm{ml}$ ) for $2 \mathrm{hr}$ prior to and during the whole experiment. HIV-1 (2.1 ng) was placed in the upper chamber and samples $(50 \mu \mathrm{L})$ were removed from the lower chamber at 18-hr (diamonds) and 66-hr (squares) intervals and measured by infectious virus assay. The relationship between $\log$ TNF- $\alpha$ and $\log$ p24 antigen concentration was significant by ANOVA $(p=0.042, F=2.747)$.

BBB permeability. RMP-7 (Alkermes, Cambridge, MA), a nonapeptide analog of bradykinin, opens up the BBB by acting on tight junctions (38). In the BBB model, both TNF- $\alpha$ and RMP-7 increased inulin permeability within the first $4 \mathrm{hr}$ similarly in a dose-responsive fashion by up to $200 \%$ (TNF- $\alpha 100 \mathrm{ng} / \mathrm{ml})(0.05<p<$ $0.10)$ and up to $225 \%$ (RMP-7 $10 \mathrm{ng} / \mathrm{ml})(0.05<$ $p<0.10$ ) (Fig. 2).

\section{Cell-Free HIV-1 and p24 Antigen Penetrate across the BBB by a Paracellular Route Opened by TNF- $\alpha$}

Previous experiments showed that BBB models built on collagen I or fibronectin have low or high paracellular permeability, respectively, and this permeability is increased by TNF- $\alpha$ or RMP-7. If cell-free HIV penetrates the barrier by a paracellular route, then the degree of virus peneiration should be increased by TNF- $\alpha$ treatment to a greater extent in the model with higher permeability. In the basal state, both models presented an efficient barrier to infectious virus for at least 3 days post-infection when tested by the infectious virus assay (Fig. 3A, B). Using a more sensitive technique, quantitative

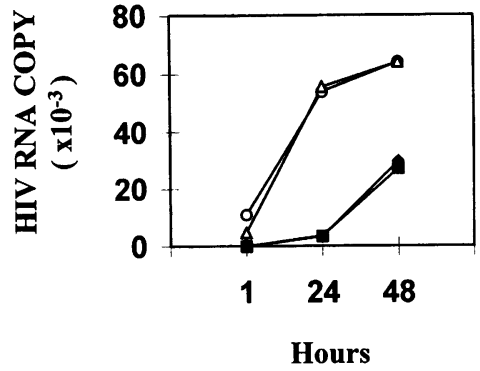

FIG. 5. Brain endothelial cells but not astrocytes or collagen I-fibronectin matrix provide a barrier to HIV-1

HIV-1 (50 pg of p24 antigen) was placed in the upper chamber of models prepared on a terephthalate membrane with no addition (open circles), collagen I and fibronectin matrix with astrocytes (open triangles), collagen I and fibronectin matrix with endothelial cells (closed squares), or collagen I and fibronectin matrix with endothelial cells and astrocytes (closed diamonds). The lower chamber samples were assayed by HIV-1 RNA assay.

RT-PCR, to determine the numbers of viral RNA copies (Figs. 3C, 5), the barrier function was found to be close to $100 \%$ for the first hour postinfection. The efficiency of the barrier at $1 \mathrm{hr}$ was evaluated as $>98 \%$, since the amount of viral RNA penetrating in $1 \mathrm{hr}$ across an uncoated membrane was 11,016 copies, whereas $<300$ copies, the lower limit of detection, penetrated the endothelial-astrocyte barrier during this time interval. Following treatment with TNF- $\alpha$, the model became increasingly permeable to the virus with time after infection and with basal permeability of each model (compare the fibronectin matrix models in Fig. 3A with the collagen I-fibronectin matrix model in Fig. 3B), and with TNF- $\alpha$ dosage (Figs. 3C and 4). ANOVA indicated that there was a significant linear relationship $(p=0.042, F=2.747)$ between log TNF- $\alpha$ concentration and $\log$ p24 antigen concentration, such that for every log unit change in TNF- $\alpha$, there was a 0.2 log unit change in p24 antigen. No threshold for TNF- $\alpha$ effect was found in the concentration range 1 to $100 \mathrm{ng} / \mathrm{ml}$ (Fig. 4).

The relative contribution of each component of the model to HIV barrier function was measured by HIV RNA assay. Brain endothelial cells provided $>99 \%$ of the barrier function, whereas astrocytes contributed negligibly either alone or together with endothelial cells (Fig. 5).

HIV-1 p24 antigen permeability was compared in models constructed on fibronectin or the collagen I-fibronectin matrix. Virus inocu- 
TABLE 2. Transmigration of monocytes across the blood-brain barrier or terephthalate membrane from the blood chamber into the brain chamber in relation to chemotactic activity of monocytes or virus in the brain chamber

\begin{tabular}{|c|c|c|c|c|}
\hline $\begin{array}{l}\text { Addition into } \\
\text { Lower Chamber }\end{array}$ & $\begin{array}{c}\text { No. of } \\
\text { Transmigrated } \\
\text { Monocytes } \\
\text { across } \\
\text { Endothelial/ } \\
\text { Astrocyte } \\
\text { Barrier } \\
\left(\times 10^{4}\right)^{c}(24 \mathrm{hr})\end{array}$ & $\begin{array}{c}\text { No. of } \\
\text { Transmigrated } \\
\text { Monocytes } \\
\text { across } \\
\text { Endothelial/ } \\
\text { Astrocyte } \\
\text { Barrier } \\
\left(\times 10^{4}\right)^{c}(48 \mathrm{hr})\end{array}$ & $\begin{array}{c}\text { No. of } \\
\text { Transmigrated } \\
\text { Monocytes } \\
\text { across } \\
\text { Uncoated } \\
\text { Membrane } \\
\left(\times 10^{4}\right)^{c}(24 \mathrm{hr})\end{array}$ & $\begin{array}{c}\text { No. of } \\
\text { Transmigrated } \\
\text { Monocytes } \\
\text { across } \\
\text { Uncoated } \\
\text { Membrane } \\
\left(\times 10^{4}\right)^{c}(48 \mathrm{hr})\end{array}$ \\
\hline None & $1.7 \pm 0.14$ & $4.1 \pm 0.25$ & $11.8 \pm 0.17$ & $16.1 \pm 0.12$ \\
\hline Monocytes $^{a}$ & $3.4 \pm 0.33$ & $6.3 \pm 0.44$ & $13.8 \pm 0.21$ & $19.6 \pm 0.35$ \\
\hline Monocytes $^{a}$ plus HIV $-1^{b}$ & $2.9 \pm 0.09$ & $8.1 \pm 0.11$ & $17.2 \pm 0.37$ & $24.9 \pm 0.07$ \\
\hline
\end{tabular}

${ }^{a} 1 \times 10^{4}$ monocytes were placed in the lower chamber.

${ }^{b} 1.5$ million copies of HIV RNA were placed in the lower chamber.

${ }^{c} 250,000$ monocytes were placed in the upper chamber. The numbers (mean \pm S.E.M.) indicate the number of monocytes that transmigrated at indicated times across the terephthalate membrane (pore size $8 \mu \mathrm{m}$ ) with or without endothelial/astrocyte bilayer into the lower chamber at indicated times.

lum (2100 pg of the antigen) was placed in the upper chamber. HIV p24 antigen efficiently penetrated the barrier in direct relation to the permeability such that $21 \mathrm{hr}$ after the infection, $91 \pm 8 \mathrm{pg} / \mathrm{ml}$ of $\mathrm{p} 24$ antigen penetrated the high-permeability fibronectin-based barrier and $50 \pm 5 \mathrm{pg} / \mathrm{ml}$ penetrated the low-permeability collagen I-fibronectin-based barrier.

\section{HIV-1 Activation of Brain Endothelial Cells for IL-6 Secretion but Not Infection}

Brain endothelial cells $(40,000)$ were exposed to HIV-1 (20 pg, $1.5 \times 10^{6}$ RNA copies) and thoroughly washed. Virus adsorption was measured after $\mathrm{l} \mathrm{hr}$ by the RNA assay, which revealed only 321 RNA copies associated with the cells. The cultures were monitored for 1 month but no infectious virus or viral antigen were released even after TNF- $\alpha$ challenge as described in Materials and Methods. The supernatant medium of virus-exposed endothelial cells, which was assayed at weekly intervals, revealed persistent IL-6 secretion with maximum titers of 54-68 $\mathrm{U} / \mathrm{ml}$, compared with unexposed cells producing at most 3-5 $\mathrm{U} / \mathrm{ml}$.

\section{HIV-1 in the Brain Compartment Attracts Transmigration of Monocytes}

The increase in monocyte infiltration of the brain with progression of AIDS dementia suggests that invading HIV-1 may be a stimulus for monocyte immigration, which is in agreement with the ability of HIV- 1 to induce macrophage inflammatory proteins- $1 \alpha$ and $-1 \beta$ (MIP- $1 \alpha$ and $-1 \beta$ ) (39). Monocyte migration was therefore assayed in the models (with or without endothelial-astrocytic bilayer) modified by inclusion of monocytes alone or with HIV-1 in the lower chamber as a chemotactic stimulus. Monocytes alone produced a slight stimulus (14-23\% increase in monocyte migration in the presence of 10,000 monocytes in the lower chamber), which was increased substantially (44-58\% increase by the addition of HIV-1 and monocytes to the lower chamber). This increase was noted at $24-48 \mathrm{hr}$ post-infection, i.e., 1 to 2 days before onset of virus replication in monocytes (39) (Table 2).

\section{DISCUSSION}

\section{Role of Brain Endothelial Cells as an HIV-1 Barrier}

The intact BBB represents an important protection against most other viremic infections but it is of only limited benefit to HIV-1-infected patients (1). The factors favoring HIV invasion across the $\mathrm{BBB}$ are difficult to evaluate by in vivo studies. Consequently, this problem was investigated by using endothelial-astrocyte bilayer models with contrasting low or high permeability. The unma- 
nipulated barrier retained infectious HIV-1 $1_{J R-F L}$ initially with close to $100 \%$ efficiency, whereas the TNF- $\alpha$-treated barrier became rapidly leaky. The in vivo BBB, which is more complex (e.g., including pericytes) and has much higher electrical resistance $(40)$, is likely to attain $100 \%$ efficiency in an undisturbed state. The breakdown of the in vitro barrier may be related to the induction of IL- 6 and other inflammatory cytokines by heavy exposure of endothelial cells to HIV-1 inoculum. This breakdown was not due to the in vitro aging of the model since the coefficient of permeability was stable for at least 7 days.

\section{HIV-1 Invades the Brain by a Paracellular Route Opened by TNF- $\alpha$ and IL-6}

The arguments favoring the paracellular nature of virus penetration of the BBB model and its augmentation by TNF- $\alpha$ include: (1) exogenous TNF- $\alpha$ enhanced both inulin (a paracellular marker) and HIV-1 penetration across the BBB model in a dose-dependent fashion without a threshold in the range 1 to $100 \mathrm{ng} / \mathrm{ml}$; (2) brain endothelial cells were activated in vitro by exposure to HIV-1 with secretion of IL-6 in a prolonged fashion but HIV-1 did not attach to or infect these cells; (3) at their basal state, the brain endothelial cells did not show rapid transfer of virus, which is observed during transcytosis of virus across epithelial barriers (6); and (4) the TNF- $\alpha$-induced increase of permeability is not associated with morphological changes of cells, although the cells display cytoplasmic stress fibers (14). These observations suggest that immune activation by autocrine and paracrine mechanisms renders brain endothelial cells permeable to HIV-1 and other molecules by a paracellular route.

There is substantial additional evidence supporting the possibility that HIV-1 gains access to the CNS in vivo by the paracellular route as a result of TNF- $\alpha$ and other cytokine effects. Brain endothelial cells of HIV-l-infected individuals become immune-activated for IL-1, IL-6, interferon- $\gamma$, and TNF- $\alpha(41,42)$. These inflammatory cytokines, including TNF- $\alpha$, IL- $1 \beta$, and IL- 6 , are found in increased amounts in the sera and the supernatants of mononuclear blood cells from HIV-1-infected individuals, and elevated serum TNF- $\alpha$ concentrations are correlated with AIDS dementia $(43,44)$. Patients with AIDS dementia demonstrate a BBB breakdown with an increased CSF:serum albumin ratio (45), and some patients' CSFs have high concentrations of HIV-1 p24 antigen $(250 \mathrm{pg} / \mathrm{ml})(46)$ and infectious virus (2-7 logs, J. McArthur, personal communication). Finally, in an in vivo rat model, TNF- $\alpha$ increases albumin leakage into the CSF (47).

In addition to the effects on endothelial cells, TNF- $\alpha$ has a wide range of pathogenetic mechanisms in patients with AIDS dementia that injure neurons and glia (35) and oligodendrocytes (48), and that increase virus replication in macrophages and microglia (49).

\section{Cell Migration and Routes of HIV-1 Brain Invasion}

In macaques inoculated with SIV, infected macrophages can be found in the brain in a perivascular location early after infection $(50,51)$. However, it is not known whether these infected macrophages represent cells migrating across the $\mathrm{BBB}$, potentially introducing the virus into the CNS, or whether perivascular macrophages are simply the initial target of SIV infection in the brain. In the BBB model used as a representation of established AIDS dementia, LPS-activated monocytes show increased ability for transmigration (11). In a similar BBB model, $\mathrm{CD}^{+}$ CD45RA ("memory") T cells show preferential transmigration compared with $\mathrm{CD} 4{ }^{+} \mathrm{CD} 45 \mathrm{RA}^{+}$ ("naive") T cells (17).

Early in HIV-1 infection of humans, proviral DNA sequences are found almost exclusively in circulating $\mathrm{CD}^{+}{ }^{+} \mathrm{T}$ cells, rather than in monocytes (52). In contrast, plasma HIV-1 viremia titer is extremely high (15). In patients with AIDS dementia, productive infection in the brain is confined almost exclusively to macrophages and microglia. On the basis of these observations, HIV-1 could potentially use several routes for brain invasion: early after the infection, it could use the paracellular route taken by cell-free virus and viral peptides, or be transported by activated $\mathrm{CD}^{+}{ }^{+} \mathrm{T}$ cells; and in a late stage, it could be transported by infected monocytes $(53,54)$.

\section{Role of Chemokines Induced by HIV-1 in Macrophage Infiltration of the Brain in HIV-1 Encephalitis}

HIV- 1 and SIV penetrating into the brain infect $\mathrm{CD}^{+}{ }^{+}$-bearing $\mathrm{T}$ lymphocytes, microglia, and perivascular macrophages (51-54). HIV-1 infection of monocytes induces MIP- $1 \alpha$ and MIP- $1 \beta$ in vitro and in vivo (39). In the in vitro model, monocyte migration into the brain compartment 
was stimulated by cell-free HIV-1 with kinetics preceding virus replication and MIP-1 production (39), which suggests that HIV-1 peptides are chemotactic for monocytes. Collectively this evidence suggests that cell-free HIV-1 and virus peptides are the first to penetrate into the brain and induce brain inflammation.

In conclusion, brain microvascular endothelial cells are the principal barrier against HIV-1 infection of the central nervous system, which upon infection is overcome by cell-free HIV-1 potentially using several routes, including a paracellular route opened by TNF- $\alpha$. The BBB model may help to identify specific cytokines and chemokines as well as their inhibitors that act on the BBB in vitro. This could lead to the identification of immune mechanisms that unravel the $\mathrm{BBB}$ in vivo and to the designing of new strategies for preventing HIV-1 infection of the brain during primary viremia.

\section{ACKNOWLEDGMENTS}

We thank O. Martinez for IL-6 titers; K. Conant, C. Tornatore, and E. Major for fetal astrocytes; T. Carlos, T. Yednock, and W. Muller for monoclonal antibodies to cell-adhesion proteins; R.T. Bartus for RMP-7; T. Raub for MDCK cells; and K. Audus, H. Gendelman, Y. Persidsky, and R. Rhodes for helpful discussions. Soo Kang, R. Stewart, and P. Villanueva provided excellent technical assistance. This work was supported by PHS grant DA 10442 and a grant from the UCLA Norman Cousin's Program in Psychoneuroimmunology to M.F.; a grant from the T.J. Martell Foundation for Leukemia, Cancer and AIDS Research and Pediatric AIDS Foundation to K.S.K.; NIH grant HL48493 to M.H.W.; and PHS grants DA 07909 and DA 04787 to P.S. This work was also supported by the UCSD Center for AIDS Research, NIH Division of AIDS, award 2 P30 AI36214-03.

\section{REFERENCES}

1. Resnick L, Berger JR, Shapshak P, Tourtellotte WW. (1988) Early penetration of the blood-brain-barrier by HTLV-III/LAV. Neurology 38: 9-15.

2. Falangola MF, Hanby A, Galvao-Castro BG, Petito CK. (1995) HIV infection of human choroid plexus: A possible mechanism of vi- ral entry into the CNS. J. Neuropathol. Exp. Neurol. 54: 497-503.

3. Brightman MW, Ishihara S, Chang L. (1995) Penetration of solutes, viruses, and cells across the blood-brain barrier. Curr. Top. Microbiol. Immunol. 202: 63-78.

4. Card JP, Rinaman L, Lynn RB, Lee B-H, Meade RP, Miselis RR, Enquist LW. (1993) Pseudorabies virus infection of the rat central nervous system: Ultrastructural characterization of viral replication, transport and pathogenesis. J. Neurosci. 113: 2515-2539.

5. Mankowski JL, Spelman JP, Ressetar HG, Strandberg JD, Laterra J, Carter DL, Clements JR, Zink MC. (1994) Neurovirulent simian immunodeficiency virus replicates productively in endothelial cells of the central nervous system in vivo and in vitro. J. Virol. 68: 8202-8208.

6. Bomsel M. (1997) Transcytosis of infectious human immunodeficiency virus across a tight human epithelial cell line barrier. Nat. Med. 3: 42-47.

7. Moses AV, Bloom FE, Pauza CD, Nelson JA. (1993) Human immunodeficiency virus infection of human brain capillary endothelial cells occurs via a CD4/galactosylceramideindependent mechanism. Proc. Natl. Acad. Sci. U.S.A. 90: 10474-10478.

8. Poland SD, Rice GPA, Dekaban GA. (1995) HIV-1 infection of human brain-derived microvascular endothelial cells in vitro. AIDS Res. Hum. Retroviruses 8: 437-445.

9. Power C, Kong P-A, Crawford TO, Wesselingh S, Glass JD, McArthur JC, Trapp B. (1993) Cerebral white matter changes in acquired immunodeficiency syndrome dementia: Alterations of the blood-brain barrier. Ann. Neurol. 34: 339-350.

10. Peluso R, Haase A, Stowring L, Edwards M, Ventura P. (1985) A Trojan horse mechanism for the spread of visna virus in monocytes. Virology 14: 231-236.

11. Persidsky Y, Stins M, Way D, Witte M, Weinand $M$, Kim K-S, Gendelman HE, Fiala M. (1997) A model for monocyte migration through the blood-brain barrier during HIV-1 encephalitis. J. Immunol. 158: 3499-3510.

12. Massari FE, Poli G, Schnittman SM, Psallidopoulos MC, Davey V, Fauci AS. (1990) Invivo $\mathrm{T}$ lymphocyte origin of macrophagetropic strains of HIV. Role of monocytes during in vitro isolatioin and in vivo infection. J. Immunol. 144: 4628-4632.

13. Gray F, Scaravilli F, Everall I, Chretin F, Shu 
A, Boche D. (1996) Neuropathology of early HIV-1 infection. Brain Pathol. 6: 1-15.

14. Deli MA, Descamps L, Dehouck M-P, Cecchelli R, Joo F, Abraham CS, Torpier G. (1995) Exposure of tumor necrosis factor- $\alpha$ to luminal membrane of bovine brain capillary endothelial cells cocultured with astrocytes induces a delayed increase of permeability and cytoplasmic stress fiber formation of actin. J. Neurosci. Res. 41: 717-726.

15. Koup RA, Safrit JT, Cao Y, et al. (1994) Temporal association of cellular immune responses with the initial control of viremia in primary human immunodeficiency virus type 1 syndrome. $J$. Virol. 68: 4650-4655.

16. Piatak M Jr, Saag MS, Yang LC, et al. (1993) High levels of HIV-1 in plasma during all stages of infection determined by competitive PCR. Science 259: 1749-1754.

17. Fiala M, Gan X-H, Newton T, Chiappelli F, Shapshak P, Kermani V, Kung MA, Diagne A, Martinez O, Way D, Weinand M, Witte M, Graves M. (1996) Divergent effects of cocaine on cytokine production by lymphocytes and monocyte/macrophage. Adv. Exp. Med. Biol. 402: 145-156.

18. Weinand ME, Wyler AR, Richey ET, Phillips BB, Somes GW. (1992) Long-term ictal monitoring with subdural strip electrodes: Prognostic factors for selecting temporal lobectomy candidates. J. Neurosurg. 77: 20-28.

19. Way D, Witte $M H$, Fiala $M$, Ramirez G, Nagle R, Bernas M, Dictor M, Witte C. (1993) Endothelial transdifferentiated phenotype and cell-cycle kinetics of AIDS-associated Kaposi sarcoma cells. Lymphology 26: 79-89.

20. Stins MF, Prasadarao DV, Ibric L, Wass CA, Luckett P, Kim KS. (1994) Binding characteristics of S fimbriated Escherichia coli to isolated brain microvascular endothelial cells. Am. J. Pathol. 145: 1228-1236.

21. Pardridge WM, Boado R, Farrell CR. (1990) Brain-type glucose transporter mRNA is selectively localized to the blood-brain barrier. J. Biol. Chem. 265: 18035-4020.

22. Farquahar MG, Palade GE. (1963) Junctional complexes in various epithelia. J. Cell Biol. 17: 375-412.

23. Tornatore C, Meyers K, Atwood W, Conant K, Major E. (1994) Temporal patterns of HIV-1 transcripts in human fetal astrocytes. J. Virol. 68: 93-102.

24. Folks T, Benn S, Rabson A, Theodore T, Hoggan MD, Martin $M$, Lightfoote $M$, Sell $\mathrm{K}$. (1985) Characterization of a T-cell line sus- ceptible to the cytopathic effects of the acquired immunodeficiency syndrome (AIDS)associated retrovirus. Proc. Natl. Acad. Sci. U.S.A. 82: 4539-4543.

25. Koyanagi Y, Miles S, Mitsuyasu RT, Merrill JE, Vinters HV, Chen ISY. (1987) Dual infection of the central nervous system by AIDS viruses with distinct cellular tropisms. Science 236: 819-822.

26. Laterra J, Goldstein GW. (1993) Brain microvessels and microvascular cells in vitro. In: Pardridge WM (ed). The Blood-Brain Barrier. Raven Press, New York, pp. 1-24.

27. Dehouck MP, Meresse S, Delorme P, Furchart JC, Ceccelli R. (1990) An easier, reproducible, and mass production method to study the blood-brain barrier in vitro. $\mathrm{J}$. Neurochem. 54: 1798-1801.

28. Fiala $M$, Rhodes RH, Shapshak $P$, Nagano I, Martinez OM, Diagne A, Baldwin G, Graves M. (1996) Regulation of HIV infection in astrocytes: Expression of Nef, TNF-alpha and IL-6 is enhanced in coculture of astrocytes with macrophages. J. Neurovirol. 2: 158-166.

29. Adson A, Raub TJ, Burton PS, Barshun CL, Hilgers AR, Audus KL, Ho NF. (1994) Quantitative approaches to delineate paracellular diffusion in cultured epithelial cell monolayers. J. Pharm. Sci. 83: 1529-1536.

30. Fogelman AM, Elahi F, Sykes K, Van Lenten BJ, Territo MC, Berliner JA. (1988) Modification of the Recalde method for the isolation of human monocytes. J. Lipid Res. 29: 1243-1247.

31. Barlow KL, Tosswill JH, Clewley JP. (1995) Analysis and genotyping of PCR products of the Amplicor HIV-1 kit. J. Virol. Methods 52: 65-74.

32. Khadir A, Coutlee F, Saint-Antoine $P$, Olivier C, Voyer H, Kessous-Elbaz A. (1995) Clinical evaluation of Amplicor HIV-1 test for detection of human immunodeficiency virus type 1 proviral DNA in peripheral blood mononuclear cells. J. AIDS Hum. Retroviruses 9: 257-263.

33. Altman DG. (1991) Practical Statistics for Medical Research. Chapman and Hall, London, p. 190.

34. Lum H, Malik AB. (1994) Regulation of vascular endothelial barrier function. Am. J. Physiol. 267 (Lung Cell Mol. Physiol. 11): L223-L241.

35. Nottet HSLM, et al. (1996) Mechanisms for transendothelial migration of HIV-l infected 
monocytes into brain. J. Immunol. 156: 1284-1295.

36. Carlos TM, Harlan JM. (1994) Leukocyteendothelial adhesion molecules. Blood 84: 2068-2101.

37. DeVries HE, Blom-Rosemalen MCM, Oosten $M$, de Boer AG, van Berkel TJC, Breimer DD, Kuiper J. (1996) The influence of cytokines on the integrity of the blood-brain barrier in vitro. J. Neuroimmunol. 64: 37-43.

38. Sanovich E, Bartus RT, Friden PM, Dean RL, Le HQ, Brightman MW. (1995) Pathway across blood-brain barrier opened by the bradykinin agonist, RMP-7. Brain Res. 705: 125-135.

39. Schmidtmayerova $H$, Nottet HSLM, Nuovo G, Raabe T, Flanagan CR, Dubrovsky L, Gendelman HE, Cerami S, Bukrinsky M, Sherry B. (1996) Human immunodeficiency virus type 1 infection alters chemokine $\beta$ peptide expression in human monocytes: Implications for recruitment of leukocytes into the brain and lymph nodes. Proc. Natl. Acad. Sci. U.S.A. 63: $700-704$.

40. Rubin LL, Hall DE, Proter S, Barbu K, Cannon C, Horner HC, Janatpour M, Liaw CW, Manning K, Morales J, Tanner LI, Tomaselli KJ, Bard F. (1991) A cell culture model of the blood-brain barrier. J. Cell Biol. 115: 1725-1735.

41. Tyor WR, Glass JD, Griffin JW, Becker PS, McArthur JC, Bezman L, Griffin DE. (1992) Cytokine expression in the brain during acquired immunodeficiency syndrome. Ann. Neurol. 31: 349-360.

42. Yoshioka M, Shapshak P, Srivastava AK, Stewart RV, Nelson SJ, Bradley WG, Berger JR, Rhodes RH, Sun NCJ, Nakamura S. (1994) Expression of HIV-1 and interleukin-6 in lumbosacral dorsal root ganglia of patients with AIDS. Neurology 44: 1120-1130.

43. Vitkovic L, da Cunha A, Tyor WR. (1994) Cytokine expression and pathogenesis in AIDS brain. In: Price RW, Perry SW (eds). $H I V, A I D S$ and the Brain. Raven Press, New York, pp. 203-222.

44. Wesselingh SL, Glass J, McArthur JC, Griffin JW, Griffin DE. (1994) Cytokine dysregulation in HIV-associated neurological disease. Adv. Neuroimmunol. 4: 199-206.

45. Singer EJ, Syndulko K, Fahy-Chandon B,
Schmid P, Conrad A, Tourtellotte WW. (1994) Intrathecal IgG synthesis and albumin leakage are increased in subjects with HIV-1 neurologic disease. J. Acquir. Immune Defic. Syndr. 7: 265-271.

46. Fiala $M$, Singer EJ, Graves $M C$, Tourtelotte WW, Stewart JA, Schable CA, Rhodes RH, Vinters HV. (1993) AIDS dementia complex complicated by cytomegalovirus encephalopathy. J. Neurol. 240: 223-231.

47. Kim KS, Wass CA, Cross AS, Opal SM. (1992) Modulation of blood-brain barrier permeability by tumor necrosis factor and antibody to tumor necrosis factor in the rat. Lymphokine Cytokine Res. 11: 293-298.

48. Wilt SG, Milward E, Zhou JM, Nagasato $K$, Patton H, Rusten R, Griffin DE, O'Connor M, Dubois-Dalcq M. (1995) In vitro evidence for a dual role of tumor necrosis factor- $\alpha$ in human immunodeficiency virus type 1 encephalopathy. Ann. Neurol. 37: 381-394.

49. Poli G, Fauci AS. (1992) The role of monocyte/macrophages and cytokines in the pathogenesis of HIV infection. Pathobiology 60: $246-251$.

50. Smith MO, Heyes MP, Lackner AA. (1995) Early intrathecal events in rhesus macaques (Macaca mulatta) infected with pathogenic or nonpathogenic molecular clones of simian immunodeficiency virus. Lab. Invest. 72: 547-558.

51. Lane JH, Sasseville VG, Smith MO, Vogel P, Pauley DR, Heyes MP, Lackner AA. (1996) Neuroinvasion by simian immunodeficiency virus coincides with increased numbers of perivascular macrophages/microglia and intrathecal immune activation. J. Neurovirol. 2: 423-432.

52. Massari FE, Poli G, Schnittman SM, Psallidopoulos MC, Davey V, Fauci AS. (1990) In vivo $T$ lymphocyte origin of macrophagetropic strains of HIV. J. Immunol. 144: 46284632.

53. Williams KC, Hickey WF. (1995) Traffic of hematogenous cells through the central nervous system. Curr. Top. Microbiol. Immunol. 202: 221-245.

54. Williams KC, Hickey WF. (1996) Traffic of lymphocytes into the CNS during inflammation and HIV infection. J. Neuro-AIDS 1: 31-55. 